

Thabiea : Journal of Natural Science Teaching

Program Studi Tadris Ilmu Pengetahuan Alam

Institut Agama Islam Negeri Kudus

http://journal.stainkudus.ac.id/index.php/Thabiea

p-issn: 25808474

\title{
Mengeksplorasi Kemampuan Berpikir Kritis Dan Rasa Ingin Tahu Siswa Melalui Kegiatan Laboratorium Inquiry Sederhana
}

Iseu Laelasari ${ }^{1, \text { a }}$, Yusuf Hilmi Adisendjaja ${ }^{2, \text { b }}$

${ }^{1}$ Program Studi Tadris IPA, Institut Agama Islam Negeri Kudus,Jl Conge Ngembalrejo PO BOX 51

${ }^{2}$ Program Studi Pendidikan Biologi, Universitas Pendidikan Indonesia, J1 Dr Setiabudhi No 229 Bandung 40154

aiseulaelasari@stainkudus.ac.id, badisenjaja@upi.edu

\begin{tabular}{ll}
\hline & ABSTRAK \\
\hline Kata kunci: & Penelitian ini merupakan studi awal yang bertujuan untuk mengeksplorasi \\
Berpikir Kritis & kemampuan berfikir kritis dan rasa ingin tahu siswa Sekolah Dasar dalam \\
Rasa Ingin Tahu & memahami sains melalui kegiatan laboratorium sederhana. Partisipan merupakan \\
Kegiatan Laboratorium & 20 siswa sekolah dasar kelas 4 yang berasal dari salah satu Sekolah Dasar di \\
Inquiry & Bandung. Peneliti menggunakan metode deskriptif untuk menggambarkan \\
Pembelajaran Sains & aktivitas siswa selama pembelajaran, gagasan siswa, dan tanggapan siswa terhadap \\
& pembelajaran yang telah dilakukan, yang diperoleh melalui komunikasi personal, \\
& lembar kerja siswa dan angket. Dalam kegiatan laboratorium pertama, peneliti \\
& menggunakan plastisin untuk mengeksplor ide siswa untuk mendesain benda \\
& tertentu dalam mengaplikasikan konsep dasar sains (fisika) mengenai konsep \\
& "terapung, melayang dan tenggelam". Dalam kegiatan kedua siswa diarahkan \\
& untuk menerapkan konsep yang telah diperoleh dari kegiatan pertama, yang mana \\
& mereka harus menyeleksi dan mengelompokkan biji kacang merah dan jagung \\
& dengan kualitas yang baik dan kurang baik yang akan mereka gunakan sebagai \\
& benih. Hasil penelitian menunjukkan bahwa kemampuan berfikir kritis dan rasa \\
& ingin tahu siswa mulai terlihat ketika mereka mendesain benda yang diperkirakan \\
& dapat melayang dan terapung di dalam air. Siswa juga antusias dalam melakukan \\
& percobaan dan berupaya untuk mencoba kembali jika desain plastisin mereka \\
& gagal. Kegiatan "trial dan error" tersebut juga menstimulasi mereka untuk terus \\
& berkreasi sehingga menemukan desain benda yang tepat. Siswa juga mampu \\
mengaplikasikan konsep tersebut dalam kehidupan sehari-hari untuk menyeleksi & dan mengelompokkan biji dengan kualitas baik dan kulitas kurang baik, dan \\
mereka antusias untuk menanam serta membandingkan pertumbuhannya. Hasil & juga menunjukkan bahwa siswa menikmati pembelajaran, tidak mengantuk dan \\
tidak bosan, serta merasa tertantang dalam melaksanakan kegiatan laboratorium \\
tersebut.
\end{tabular}

\footnotetext{
Key word:

Critical Thinking

Student Curiosity

Laboratory Activity

Inquiry

Science Learning
}

\begin{abstract}
Exploring Critical Thinking And Students Curiosity Through Simple Inquiry Laboratory Activity. This study is a preliminary research to explore critical thinking skills and students curiosity of primary school in understanding science through simple inquiry laboratory activities. Participants are 20 students of $4^{\text {th }}$ grade from one of the primary schools in Bandung. The researcher uses descriptive method to describe student activity during learning, student idea, and student's response in learning, obtained through personal communication, student worksheet and questionnaire. In the first lab activity, researchers used plasticine to explore students' ideas for design 3 objects for exploring science concept namely "floating, drifting and sinking. In the second activity students are directed to apply the concept that has been obtained in the first activity, which is they should selecting and classify red bean and corn with good quality and bad quality that used to be seeds. The results show that critical thinking ability and students curiosity begin look when they design objects that are expected for floating and drifting. Students are enthusiastic about experimenting and trying to recreate if their plasticine design fails. Trial and error activities are also stimulate them to continue their idea to find the right design objects. That concepts can be applied by student in daily life to select and classify seeds with good and less quality, and they are enthusiastic to plant it and compare it growth. Results also show that students enjoy learning, not sleepy and bored, and feel challenged.
\end{abstract}

Copyright (C) 2018 Institut Agama Islam Negeri Kudus. All Right Reserved 


\section{Pendahuluan}

Schafersman (1997) berpendapat bahwa berpikir kritis merupakan cara berpikir dengan benar dalam rangka pencarian pengetahuan yang relevan dan reliabel tentang sesuatu yang terdapat di sekitar kita. Berpikir kritis mengacu pada cara berpikir yang masuk akal (reasonable), reflektif, berbertanggung jawab, dan berpikir cakap dan terampil yang semuanya itu dipusatkan untuk memutuskan apa yang harus dipercayai atau dilakukan (Thohari, 2010). Bersesuaian dengan apa yang dikemukakan oleh Ennis (1996), bahwa berpikir kritis merupakan berpikir masuk akal (didasarkan pada faktafakta) dan reflektif (mencari kemungkinan solusi terbaik secara sadar dan tegas) yang difokuskan pada pengambilan keputusan tentang apa yang dilakukan atau diyakini.

Berfikir kritis merupakan bagian dari Habits of Mind (HoM) dan juga termasuk ke dalam High Order Thinking Skill (Marzano, 1992). Sebagai bagian dari Habits of Minds, berfikir kritis perlu dilatihkan dari mulai kegiatan pra sekolah dan juga Sekolah Dasar, sehingga siswa terbiasa untuk mengembangkan kemampuan berfikir mereka pada jenjang sekolah berikutnya. Paul \& Nosich (Inch, et al., 2006) mengemukakan bahwa mengembangkan kemampuan berpikir kritis siswa diperlukan pada zaman sekarang ini karena seseorang yang memiliki kemampuan berpikir kritis dapat terhindar dalam membuat keputusan atau pemecahan masalah yang keliru.

Seorang guru harus mampu merancang dan mengemas pembelajaran sains supaya dapat dinikmati oleh siswa sebagai pembelajaran yang menyenangkan. Di tingkat Sekolah Dasar, guru dapat memanfaatkan pembelajaran sains sebagai wahana untuk menstimulasi keterampilan berfikir kritis yang melibatkan siswa secara langsung melakukan pengalaman sains melalui kegiatan menggunakan berbagai indera yang dimiliki (hands on) untuk kemudian mengkonstruk hasil dan temuan mereka menjadi suatu pengetahuan (minds on).

Salah satu pembelajaran yang dapat menunjang kegiatan hands on dan minds on tersebut adalah kegiatan praktikum/ kegiatan laboratorium. Pembelajaran berbasis laboratorium memungkinkan siswa untuk mengalami prinsip bioscience pertama. Dengan demikian penting untuk mengeksplorasi pendekatan alternatif untuk memaksimalkan potensi belajar dalam praktek laboratorium (Crocker, 2011). Menurut $\mathrm{Wu}$ (2013) pengalamam laboratorium memiliki peran sentral dalam pendidikan sains. Banyak manfaat yang diperoleh siswa ketika mereka terlibat dalam kegiatan laboratorium.

Hal tersebut juga berkaitan dengan hakikat sains sebagai suatu produk, proses dan sikap ilmiah. Sains sebagai suatu produk menunjukkan bahwa di dalam sains terdapat sejumlah fakta, hukum, prinsip, dan teori-teori yang kebenarannya sudah dapat diterima. Sementara sains sebagai proses mengandung arti bahwa diperlukan suatu proses tertentu yang harus dilakukan untuk memperoleh suatu pengetahuan (Rustaman et al., 2003). Proses ini akan melibatkan siswa untuk aktif menemukan pengetahuan (process objectives) (Supriatno, 2009). Pengetahuan yang dimaksud bukan sekedar pengetahuan deklaratif (pengetahuan tentang apa sesuatu itu), melainkan juga pengetahuan prosedural (pengetahuan tentang bagaimana melakukan sesuatu) (Dahar, 1996).

Pengalaman langsung yang lebih dikenal dengan learning by doing, akan memberikan kesan paling utuh dan paling bermakna mengenai informasi dan gagasan yang terkandung karena melibatkan indera penglihatan, pendengaran, peraba, penciuman dan pengecapan (Supriatno, 2009). Senada dengan apa yang dikemukakan oleh Siritunga $e t$ al (2011) bahwa penelitian atau latihan laboratorium berbasis inquiry dilakukan untuk meningkatkan keterampilan berfikir kritis, retensi pengetahuan, keterampilan teknis yang diperoleh, dan meningkatkan minat siswa.

Hasil studi pendahuluan yang dilakukan melalui komunikasi personal dengan tiga guru yang mengajar di Sekolah Dasar di Bandung, diketahui bahwa mereka jarang melaksanakan kegiatan eksperimen ataupun inquiry sebagai bagian dalam pembelajaran, walapun pada dasarnya mereka mengetahui bahwa kegiatan 
tersebut penting untuk dilakukan. Hal tersebut dikarenakan terbatasnya waktu pembelajaran yang disediakan dan kurang tersedianya fasilitas laboratorium di tingkat SD. Padahal kegiatan laboratorium di tingkat SD bisa dirancang sesederhana mungkin dengan memanfaatkan bahan dan material yang mudah ditemukan dilingkungan sekitar dengan harga terjangkau.

Berkaitan dengan hal tersebut, peneliti tertarik untuk merancang kegiatan laboratorium sederhana berbasis inquiry dengan menggunakan alat dan bahan praktikum yang dengan mudah dapat diperoleh di lingkungan sekitar. Kegiatan ini dilakukan sebagai studi awal untuk melihat respon siswa dan juga efektivitas penerapan kegiatan labaoratorium dalam mengeksplorasi kemampuan berfikir kritis dan rasa ingin tahu siswa di Sekolah Dasar yang jarang melaksanakan kegiatan laboratorium.

\section{Metode}

Penelitian dilakukan di salah satu Sekolah Dasar di Bandung, dengan melibatkan 20 siswa kelas 4 sebagai parsipan. Peneliti menggunakan metode deskriptif untuk menggambarkan aktivitas siswa selama pembelajaran, ide yang digagas siswa, dan tanggapan siswa terhadap pembelajaran yang telah dilakukan. Instrumen yang digunakan untuk mengumpulkan data berupa lembar kerja siswa dan angket serta ditunjang oleh lembar komunikasi personal, yang kemudian data dianalisis secara kualitatif untuk memperoleh gambaran mengenai kemampuan berfikir kritis dan rasa ingin tahu siswa. Dalam merancang Kegiatan laboratorium ikuiri pertama, peneliti menggunakan 3 bahan yaitu: plastisin, gelas bekas air mineral dan juga air sebagai bahan untuk mengeksplor ide siswa dalam mendesain tiga benda yang masing-masing diperkirakan dapat "terapung, melayang dan tenggelam. Dalam pembelajaran yang dilakukan siswa bekerja secara berkelompok yang masingmasing anggota kelompok berjumlah 4 siswa. Masing-masing kelompok diberikan lembar kerja yang harus diisi dengan gagasan siswa terkait desain-desain benda yang akan dibuat, sampai mereka berhasil membuat benda yang cocok. Siswa juga diminta untuk menuliskan rekam jejak kegiatan trial dan error yang mereka lakukan. Setelah mereka melakukan kegiatan laboratorium pertama, masing-masing kelompok melanjutkan kegiatan lab kedua. Dalam kegiatan ini siswa diberi permasalahan untuk memilih benih jagung dan kacang merah, kemudian mereka harus memilih, menyeleksi dan mengklasifikasikan benih-benih yang memiliki kualitas baik dan kurang baik dengan menggunakan konsep yang telah mereka bangun pada kegiatan lab pertama. Setelah mereka memilih, menyeleksi dan mengklasifikasikan, mereka melakukan proyek kegiatan untuk menanam jagung dan kacang merah tersebut pada pot yang berbeda, serta membandingkan pertumbuhannya.

\section{Hasil dan pembahasan}

Siswa mampu membuat 3 bentuk benda menggunakan plastisan yang pada umumnya berbentuk bulat seperti kelereng untuk model benda tenggelam, berbentuk bulat berongga untuk model benda melayang dan berbentuk seperti perahu untuk benda terapung. Adapun Data tersebut disajikan pada Tabel - Tabel berikut ini.

Tabel 1 Rancangan Bentuk Objek Terapung

\begin{tabular}{ccc}
\hline Kelompok & Bentuk objek & $\begin{array}{c}\text { Jumlah } \\
\text { percobaan }\end{array}$ \\
\hline 1 & Seperti mangkuk & 2 \\
\hline 2 & Seperti perahu & 3 \\
\hline 3 & Seperti perahu & 3 \\
\hline 4 & Seperti perahu & 3 \\
\hline 5 & Seperti mangkuk & 3 \\
\hline
\end{tabular}

Tabel 2 Rancangan Bentuk Objek Melayang

\begin{tabular}{ccc}
\hline Kelompok & Bentuk objek & $\begin{array}{c}\text { Jumlah } \\
\text { percobaan }\end{array}$ \\
\hline 1 & Bulat berongga & 4 \\
\hline 2 & Bintang berongga & 5 \\
\hline 3 & Seperti bunga & 5 \\
\hline 4 & Bulat berongga & 5 \\
\hline 5 & Oval berongga & 6 \\
\hline
\end{tabular}


Tabel 3 Rancangan Bentuk Objek Tenggelam

\begin{tabular}{clc}
\hline Kelompok & Bentuk objek & $\begin{array}{c}\text { Jumlah } \\
\text { percobaan }\end{array}$ \\
\hline 1 & Bulat pejal & 1 \\
\hline 2 & Bulat pejal & 1 \\
\hline 3 & Oval pejal & 1 \\
\hline 4 & Bulat pejal & 1 \\
\hline 5 & Oval pejal & 1 \\
\hline
\end{tabular}

Berdasarkan Tabel 1, 2 dan 3 dapat diketahui bahwa kemampuan berfikir kritis dan rasa ingin tahu siswa mulai terstimulasi ketika mendesain benda terapung dan melayang. Hal tersebut terlihat dari jumlah pecobaan yang dilakukan sampai berhasil mendesain bentuk yang paling sesuai. Jumlah percobaan tersebut juga berbanding lurus dengan tingkat kesulitan, daya juang siswa dan rasa ingin tahu siswa. Dalam hal ini Siswa paling mengalami kesulitan untuk membentuk benda melayang dengan ratarata 5 kali percobaan, dibandingkan dengan benda terapung dengan rata-rata 3 kali percobaan. Hal ini dimungkinkan karena siswa belum bisa memperkirakan bagaimana caranya supaya benda tersebut memiliki masa jenis yang sama dengan air. Karena dalam hal ini peneliti tidak mengemukakan konsep massa jenis air maupun massa jenis benda yang berkaitan dengan konsep terapung, melayang dan tenggelam. Hal tersebut bertujuan supaya siswa tidak di bebani dengan konsep sains yang bersifat abstrak, yang bisa dipelajari siswa pada jenjang sekolah selanjutnya.

Dalam pembelajaran ini siswa mengkonstruksi sendiri definisi ketiga konsep tersebut setelah dilakukan demonstrasi menggunakan paku, kelereng, gabus, korek api, karet gelang yang dicelupkan ke dalam air dan junga menunjukan gambar ilustrasi. Melalui kegiatan tersebut siswa mendefinisikan bahwa jika sebagian atau seluruh bagian benda berada di atas permukaan air disebut terapung, jika seluruh bagian benda berada di dalam air tetapi tidak menyentuh dasar air maka disebut melayang, sedangkan definisi tenggelam adalah ketika benda menyentuh dasar permukaan air. Berangkat dari konsep tersebut, melalui aktivitas laboratorium sederhana ini, nampak upaya siswa untuk berkreasi untuk membentuk dan memperkirakan ketiga benda tersebut.

Berdasarkan hasil pengamatan aktivitas siswa, siswa berdiskusi secara aktif dengan kelompok belajarnya maupun berinteraksi dengan anggota kelompok lain. Interaksi tersebut mendorong kelompok siswa yang belum berhasil membentuk benda untuk meniru bentuk benda yang berhasil di desain oleh kelompok lainnya, walaupun ketika benda tersebut ditiru oleh kelompok lain tidak serta merta langsung berhasil, terutama untuk benda melayang. Pada akhirnya mereka tetap harus berfikir kembali untuk berhasil membentuk benda yang diharapkan. Aktivitas ini menunjukan bahwa diperlukan cara berpikir yang masuk akal (reasonable), reflektif, berbertanggung jawab, dan berpikir cakap dan terampil yang semuanya itu dipusatkan untuk memutuskan apa yang harus dilakukan (Thohari, 2010). Bersesuaian dengan apa yang dikemukakan oleh Ennis (1996), bahwa berpikir kritis merupakan berpikir masuk akal (didasarkan pada fakta-fakta) dan reflektif (mencari kemungkinan solusi terbaik secara sadar dan tegas) yang difokuskan pada pengambilan keputusan tentang apa yang dilakukan atau diyakini.

Beberapa kali siswa mengulang untuk mendesain benda dengan bentuk yang sama namun dengan proporsi plastisin yang berbeda, sampai mereka menemukan bahwa model benda dengan bentuk bulat ataupun oval yang di dalamnya diberi rongga/ ruang, merupakan bentuk benda yang berhasil di desain sebagai contoh benda melayang. Proses tersebut bersesuaian dengan pernyataan yang dikemukakan oleh Siritunga, et al (2011) bahwa penelitian atau latihan laboratorium berbasis inquiry dilakukan untuk meningkatkan keterampilan berfikir kritis. Pada tahap selanjutnya perwakilan kelompok siswa untuk mengomunikasikan hasil percobaan mereka, dengan tujuan supaya mereka bisa berbagai pengalaman dalam proses inquiry yang mereka lakukan. 
Dalam kegiatan laboratorium kedua, siswa diarahkan untuk menerapkan konsepkonsep yang telah diperoleh dalam aktivitas pertama untuk dimanfaatkan dalam kehidupan sehari-hari. Dalam hal ini siswa melakukan kegiatan untuk menyeleksi dan mengelompokkan biji kacang merah dan jagung yang memiliki kualitas terbaik sampai dengan kurang baik. Di awal kegiatan siswa diminta untuk memperkirakan apakah kacang akan mengapung, melayang, atau tenggelam, dan umumnya siswa menyebutkan tenggelam jika dimasukkan ke dalam air. Untuk menemukan jawaban, siswa diarahkan untuk melakukan kegiatan dengan memasukkan benih ke dalam gelas air mineral yang telah di isi dengan air, kemudian mereka mengamati dan menyeleksi biji-bijian yang mengambang, mengapung, dan tenggelam di air, dan mengelompokkannya ke dalam 3 wadah yang berbeda. Selanjutnya, siswa diarahkan untuk menentukan kualitas benih dari yang tertinggi ke yang terendah, menurut pendapat mereka sendiri dan mengemukakan alasannya.

Hasilnya menunjukkan bahwa secara keseluruhan para siswa berhasil memilah kacang dengan tepat. Melalui pertanyaan yang dikemukakan langsung oleh peneliti, $85 \%$ siswa menjawab bahwa biji yang memiliki kualitas terbaik untuk ditanam adalah biji yang tenggelam, dengan alasan bahwa biji-biji tersebut paling banyak mengandung isi dibandingkan dengan yang lainnya. Di tahap berikutnya siswa memilih beberapa biji jagung dan kacang merah dengan kualitas baik dan kurang baik sesuai dengan pilihan mereka sendiri sebagai bibit untuk ditanam di pot yang berbeda. Setiap kelompok siswa dipandu untuk mengamati pertumbuhan setiap benih untuk memverifikasi konsep mereka. Kegiatan ini dilakukan oleh peneliti untuk lebih merangsang rasa ingin tahu siswa, dan mereka tertarik untuk melakukan percobaan ulang sehingga mereka dapat mengembangkan pengalaman belajar dan memaksimalkan potensi mereka dengan menemukan hal-hal baru. Hasil ini terkait dengan pendapat Crocker (2011) bahwa pembelajaran berbasis laboratorium memungkinkan siswa untuk mengalami prinsip bioscience pertama dan dapat memaksimalkan potensi belajar dalam praktik laboratorium.

\section{Simpulan}

Kegiatan laboratorium inquiry sederhana melalui penggunaan plastisin untuk mendesain tiga bentuk benda dalam rangka mengaplikasikan konsep benda terapung, melayang dan tenggelam, kemudian menerapkan ketiga konsep tersebut dalam kehidupan sehari-hari untuk menyeleksi dan mengelompokkan benih dengan kualitas baik dan kurang baik, yang selanjutnya melakukan kegitan verifikasi dengan menanam benih tersebut, mengamati dan membandingkan pertumbuhannya, dapat mengeksplor kemampuan berfikir kritis dan rasa ingin tahu siswa dalam pembelajaran sains, sehingga siswa lebih antusias menikmati pembelajaran, tidak mengantuk dan tidak bosan, serta merasa tertantang untuk mengulangi kegiatan laboratorium tersebut.

\section{Referensi}

Croker, K., et al. (2010). Enhancing The Student Experience of Laboratory Practicals Throught Digital Video Guides. Bioscience Education. Vol 16.

Dahar, R, W. (1996). "Teori-Teori Belajar". Jakarta: Erlangga.

Ennis, R. H. (1996) Critical thinking. Upper Saddle River, NJ: Prentice-Hall.

Inch, E. S., et al. (2006). Critical Thinking and Communication: The use of reason in argument. 5th Ed. Boston: Pearson Education, Inc.

Marzano, et al. (1992). Assesing Student Outcomes: Performance Assesment Using the Dimensions of Learning Models. Alexandria, Virginia : Association for Supervision and Currciculum Development.

Rustaman, N., et al. (2003). "Strategi Belajar Mengajar Biologi". Bandung: Jurusan Pendidikan Biologi. 
Schafersman, S. D. (1997). An Introduction to Critical Thinking. Tersedia: http://www.freeinquiry.com/criticalthinking.html.

Spell, R.M., et al. (2014). Redefining Authentic Research Experiences in Introductory Biology Laboratories and barriers to Their Implementation. CBE-Life Science Education. Vol.13, 102-110.

Sritunga, D., et al. (2011). Culturally Relevant Inquiry Based Laboratory Module Implementation in Upper-Division Genetics and Cell Biology Teaching Laboratories. CBE-Life Science Education. Vol.12, 460-470.
Supriatno, B. (2009). "Uji Langkah Kerja Laboratorium Biologi Sekolah". Proseding Seminar Nasional Jurusan Pendidikan biologi: Tidak Diterbitkan.

Thohari, K. (2010). Peningkatan Kemampuan Problem Solving melalui Peningkatan Kemampuan Metakognisi. Online. Tersedia: http://journal.um.ac.id.

$\mathrm{Wu}$, J. (2013). Mutation Based Learning to Improve Student Autonomy and Scientific Inquiry Skills in a Large Genetics Laboratory Course. CBELife Science Education. Vol.12, 460470. 